\title{
Open data for democracy: Developing a theoretical framework for open data use
}

\author{
Erna Ruijer *, Stephan Grimmelikhuijsen, Albert Meijer \\ Utrecht University, School of Governance, Bijlhouwerstraat 6, 3511 ZC Utrecht, Netherlands
}

\section{A R T I C L E I N F O}

\section{Article history:}

Received 13 March 2016

Received in revised form 18 October 2016

Accepted 1 January 2017

Available online 10 January 2017

\section{Keywords:}

Democracy

Open government data

Open data platform

\begin{abstract}
A B S T R A C T
Open data platforms are hoped to foster democratic processes, yet recent empirical research shows that so far they have failed to do so. We argue that current open data platforms do not take into account the complexity of democratic processes which results in overly simplistic approaches to open data platform design. Democratic processes are multifaceted and open data can be used for various purposes, with diverging roles, rules and tools by citizens and public administrators. This study develops a Democratic Activity Model of Open Data Use, which is illustrated by an exploratory qualitative multiple case study outlining three democratic processes: monitorial, deliberative and participatory. We find that each type of democratic process requires a different approach and open data design. We conclude that a context-sensitive open data design facilitates the transformation of raw data into meaningful information constructed collectively by public administrators and citizens.
\end{abstract}

(c) 2017 Elsevier Inc. All rights reserved.

\section{Introduction}

One important underlying condition of a properly functioning democracy is access to information (Harrison \& Sayogo, 2014). Informed citizens are better able to contribute to democratic processes, better able to understand and accept the basis of decisions affecting them and better able to shape the situations in which they live (Birkinshaw, 2006; Meijer, Curtin, \& Hillebrandt, 2012). Several scholars have pointed out that open data platforms aim to foster democratic processes by promoting transparency through the publication of government datasets and by providing the opportunity to actively participate in government processes such as decision-making, policy-making and solving public problems (Verhulst \& Young, 2016; Attard, Orlandi, Scerri, \& Auer, 2015; Lourenço, 2015; Dawes \& Helbig, 2010; Janssen, 2011). Open data platforms are also aimed at stimulating innovation, economic growth and at improving service delivery (Verhulst \& Young, 2016; Janssen, Charalabidis, \& Zuiderwijk, 2012; Huijboom \& Van den Broek, 2011). However this study focuses on to the value of open data for democracy.

To improve open data usage, several studies have focused on identifying general user requirements such as timeliness, completeness, visibility and quality of data (Lourenço, 2015; Van Velzen, Van der Geest, \& Ter Hedde, 2009; Jaeger, Bertot, \& Shilton, 2012). However, this may not be enough given the limited use of open government data for democratic purposes (Worthy, 2015; Attard et al., 2015). A general shortcoming of current approaches to open data is that they do not conceptualize

\footnotetext{
* Corresponding author.

E-mail address: h.j.m.ruijer@uu.nl (E. Ruijer).
}

the diverging roles that citizens have (e.g. individual citizens, members of civic society, and the private sector), nor the roles of government (e.g. public administrators, politicians, managers) in democratic processes and focus on the information they ask instead of the information they need to actively contribute to democratic processes.

In response, this article argues that next to these general user requirements we need to take into account the context of open data use that includes people and their relations as well (Kuuti, 1999) to assure that an open data platform facilitates user activities in varying democratic settings. Often this context of broader social forces and structures that influences the interaction between users and information technology is left unexamined (Engeström, 2005). Modelling this context into open data platform design is crucial to develop a platform that works for users in their specific democratic context. A contextual approach is needed to model the interplay between social actors, their stakes in open data, their roles and motivations, constraints and systems of ideas.

The aims of this study are threefold: (a) a better conceptual understanding of the relation between open data and various types of democratic processes, (b) a better explanatory model of the challenges for open data use for democracy and (c) a basis for context-sensitive design of open data platforms. Based on literature on democracy, monitorial, deliberative and participatory democracy are identified as three distinct processes that influence the use of open data. For each democratic process we will explore the expected role of citizens and of government.

In addition, to model the activities of citizens and of governments, we use Activity Theory. Activity Theory can be used to understand human activities within social and organizational contexts (Ojo, Janowski, \& Estevez, 2011). It has been used as a framework for human-computer interaction research (Kuuti, 1996) and can therefore 
help us understand how open data can contribute to the flow of information between citizens and government in a democratic context.

Based on these two strands of literature, we develop the Democratic Activity Model of Open Data Use (DAMODU). This is not a model in the theoretical-deductive sense, with derived hypotheses and quantitative testing, but an explanatory heuristic model that can be used to better understand open data practices in a democratic context. To show the value of this model, an exploratory multiple case study is conducted that focuses on varying issues: Budget Management (Prato, Italy), Capacity Building (Dublin, Ireland) and Population Decline (Groningen, The Netherlands). These cases illustrate three different democratic processes: monitorial, deliberative and participatory. It shows respectively how open data can contribute by allowing citizens and government to monitor and analyze public problems, how open data can contribute to deliberation about public problems and how open data can contribute to joined action in finding solutions for public problems (Verhulst \& Young, 2016; Noveck, 2015).

The DAMODU contributes to the literature in the following ways. First, unlike the user requirement studies, the democratic context is explicitly modeled. Our design approach positions users in democratic contexts as a starting point for the design of open data platforms. Second, it shows the interplay between social actors in the provision and use of open data, what is at stake for them, their roles and motivations, constraints and systems of ideas and how this influences the use of an open data platform for democratic processes. Third, this context is not just seen as one between government and individual citizens but between government and networks of citizens, communities that collectively attribute meanings to the information.

In the next section the DAMODU will be developed based on Democratic and Activity Theory. Following, the research method is described and the results of the different cases presented. After analyzing and discussing the different cases, conclusions are drawn that provide insights in the context of open data use.

\section{Democratic Activity Model of Open Data Use (DAMODU)}

\subsection{Democratic processes: Monitorial, deliberative or participatory?}

Democracy is not a one-dimensional concept (Strömbäck, 2005) and therefore this study highlights the variety in democratic processes and the differences in information requirements. In this study, three interconnected democratic processes are distinguished: monitorial, deliberative and participatory democracy (Meijer, 2012).

\subsubsection{Monitorial democracy}

The idea of a monitorial democracy is drawn from the work of Keane (2009) and Schudson (1998). The basic premise behind a monitorial democracy is that government obtains a mandate from the people to rule. The way this mandate is used is monitored and the mandate can be revoked if it is abused. It is a form of democracy in which power-monitoring has perpetrated government and society (Keane, 2009).

The role of citizens in a monitorial democratic process can be characterized as being well informed, watchful and holding government accountable. They engage in surveillance without really being pro-active responders. "The monitorial citizen is not an absentee citizen but watchful, even while he or she is doing something else." (Schudson, 1998, p. 311). This implies that citizens do not know all the issues all the time but that "...they should be informed enough and alert enough to identify danger to their personal good and danger to the public good" (Schudson, 2000, p. 16). Monitorial citizens are aware that they need to keep an eye on politics but allow intermediary institutions to play the most important role. The media in this context serve as a "firealarm" (Coleman \& Moss, 2012, p. 2) to alert citizens about matters requiring urgent attention. The focus is on what information citizens need in order to hold officials accountable in elections (Zaller, 2003). Monitoring is crucial for reducing corruption and agency-drift: if citizens can monitor how officials spend money and allocate resources they can check whether this is in line with legal rules and the will of the people.

The role of government in a monitorial democratic process is to disclose information, either proactively on its own initiative, or reactively based on a freedom of information (FOI) request (Meijer et al., 2012; Ruijer, 2016) or for instance in line with the European Directive (2013/37/EU) on the reuse of public sector information (Janssen, 2011). An open data platform could contribute to strengthening access to government information so that citizens are able to scrutinize government performance.

\subsubsection{Deliberative democracy}

Deliberative democracy highlights that an open debate is needed to find collective solutions to public problems (Habermas, 1989). Deliberation, rather than voting, is seen as the central mechanism for political decision-making (Meijer, 2012, p. 305). Deliberation is focused on opinion formation and the general will (Noveck, 2009, p. 39). Viewpoints and information from a variety of angles are needed to discuss different options and to find an optimal solution.

The role of citizens is one of a partner in deliberative processes. Citizens need information to see what is going on inside government organizations and they need to participate to voice their opinions (Meijer et al., 2012, p. 11). Citizens are discussing their views about what government should or should not do. This implies that citizens are indirectly related to decision-making and action (Noveck, 2009). Civil society produces public opinion which filtered through the mass media, influences the government agenda (Noveck, 2015, p. 93). Furthermore, citizens need to be interested and engaged from the viewpoint of this process (Strömbäck, 2005). It requires commitment to the public cause, which according to Van den Hoven (2005) can be time consuming and the average citizen might not always be willing to deliver. Motivational factors to participate differ (Wijnhoven, Ehrenhard, \& Kuhn, 2015). When citizens feel that their contribution is really meaningful they will be more motivated to engage. The input from more citizens is expected to result in better-argued and more legitimate government policies.

The role of government is to invite citizens to present their opinions and perspectives on issues. This can be done offline by organizing town hall meetings, or online. ICT's and open data could strengthen a deliberative democracy by creating a level playing field for all participants in the public debate and engaging citizens (Van den Hoven, 2005; Meijer, 2012). Governments coordinating a platform should examine every suggestion and give precise feedback why certain ideas or parts of it can or cannot be implemented (Wijnhoven et al., 2015). Participants are more likely to engage if they believe that their ideas and suggestions will be implemented correctly and with caution (Wijnhoven et al., 2015, p.39). An open data platform could contribute to strengthening deliberation between citizens, and between citizens and government, for instance by offering a virtual discussion platform that allows conversation and dialogue (Dalakiouridou, Smith, Tambouris, \& Tarabanis, 2012; Noveck, 2015)

\subsubsection{Participatory democracy}

A participatory democracy puts an emphasis on joined action and collaboration. The basic idea of a participatory democracy is that citizens do not only give a mandate to government but they can also actively engage and collaborate directly in the solution of societal problems, the production of services and policies and the implementation of policies in a variety of policy domains (Strömbäck, 2005; Meijer, 2012). Collaboration occurs throughout the decision-making process (Noveck, 2009). It "catalyzes new problem-solving strategies, in which public and private sector organizations and individuals solve social problems collectively" (Noveck, 2009, p. xiii). Collaboration is necessary to generate creative solutions to challenges and to share the work of oversight and accountability (Noveck, 2009). 
The role of citizens in participatory processes is not only to give a mandate to government, or deliberate about issues, but they also actively engage and collaborate directly in the solution of public problems, the production of services and policies and the implementation of policies in a variety of policy domains (Strömbäck, 2005; Meijer, 2012). They are co-creators of public goods. Citizens can contribute their expertise and thereby realizing the opportunity to be powerful (Noveck, 2009). They can become volunteers of the police, set up helpdesks for tax declarations, help to clean their neighborhoods, etc. (Boyte, 2005).

The role of government shifts in this democratic processes from provider of services to partner (Boyte, 2005). Open data platforms can make it easier for citizens, organizations and businesses to interact and collaborate with government organizations by offering a collaborative environment and enable participation in collective decision-making efforts about public problems (Janssen, 2011;Dalakiouridou et al., 2012; Sandoval-Almazan \& Gil-Garcia, 2012; Wijnhoven et al., 2015; Attard et al., 2015; Noveck, 2015).

\subsection{Activity theory}

Hence open data usage may vary in different democratic processes. In this section the context of open data usage will be further examined by using Activity Theory. Activity Theory has been used as a framework for human computer interaction research (Kuuti, 1996). Activity theory focuses on the activities that people engage in, who is engaging in that activity and what their goals and intentions are, what objects or products result from the activity, the rules and norms that circumscribe the activity and the community in which the activity occurs (Jonassen \& Rohrer-Murphy, 1999, p. 62). An activity is a collective form of doing directed to and driven by an object (Engeström, 2008; Kuuti, 1996). Activities are open systems (Engeström, 2001). They are continuously changing and developing (Nardi, 1996; Kuuti, 1996). Fig. 1 shows the seven components of the activity model (Engeström, 2000):

a) subject: the individual or group of actors engaged in the activity (Jonassen \& Rohrer-Murphy, 1999);

b) object: the physical or mental entity towards which the activity is oriented, that motivates the activity (Jonassen \& Rohrer-Murphy, 1999);

c) tools: mediate and alter the activity and that can in turn be altered by the activity (Jonassen \& Rohrer-Murphy, 1999);

d) community: consists of all actors directly involved in an activity, sharing the object with the subject (Ojo et al., 2011);

e) rules: the explicit and implicit norms, conventions and social relations of a community (Kuuti, 1996; Ojo et al., 2011) that guide the actions or activities acceptable by the community (e.g. legal framework) (Jonassen \& Rohrer-Murphy, 1999);

f) division of labor: roles (Ojo et al., 2011) that prescribe the task specialization by individual members of the group within the community (Jonassen \& Rohrer-Murphy, 1999);

g) outcome: the transformation of the object into an outcome motivates the existence of an activity (Kuuti, 1996).

An activity system is characterized by a community of multiple points of view, multiplied in networks of interacting activity systems. Furthermore, activity systems take shape and get transformed over lengthy periods of time. Tensions within the system are seen as sources of change and development (Engeström, 2001).

\subsection{Towards a model}

Combining democracy theory and activity theory results in the Democratic Activity Model of Open Data Use. The DAMODU (see Fig. 2), the activity concerns the use of open data in three different contexts: monitorial, deliberative and participatory democratic processes. In the model citizens and public administrators can be considered as two interacting activity systems (Engeström, 2001).

Within the activity system of citizens, the subject can then either be a citizen as a watchdog in monitorial processes, a partner in dialogue in deliberative processes and a partner in joined action in participatory democratic processes. The object of the use of open data can be government performance (monitorial) or a public problem (deliberative and participatory). The open data platform is the mediating tool that facilitates the interaction between the activity systems of the citizen and public administrator. The open data platform should display and provide accessible and understandable data regarding the object so that citizens are able to scrutinize government performance (monitorial), but should also provide functionalities for interaction, feedback options and channels for participation through e.g. the use of online forums (deliberative), and opportunities for co-creation and collaboration with public administrators or other citizens (participatory) (SandovalAlmazan \& Gil-Garcia, 2012). Rules refer to legal frameworks such as Freedom of Information laws (FOI's) that give citizens a right to request information and to the European Directive (2013/37/EU) on the reuse of public sector information. But it also refers to informal rules and strategies within the community: who participates and collaborates? Who is invited? A community can consist of other interested citizens but also of journalists, researchers, individual technology developers, businesses and public administrators. The roles of the actors differ. Journalists can

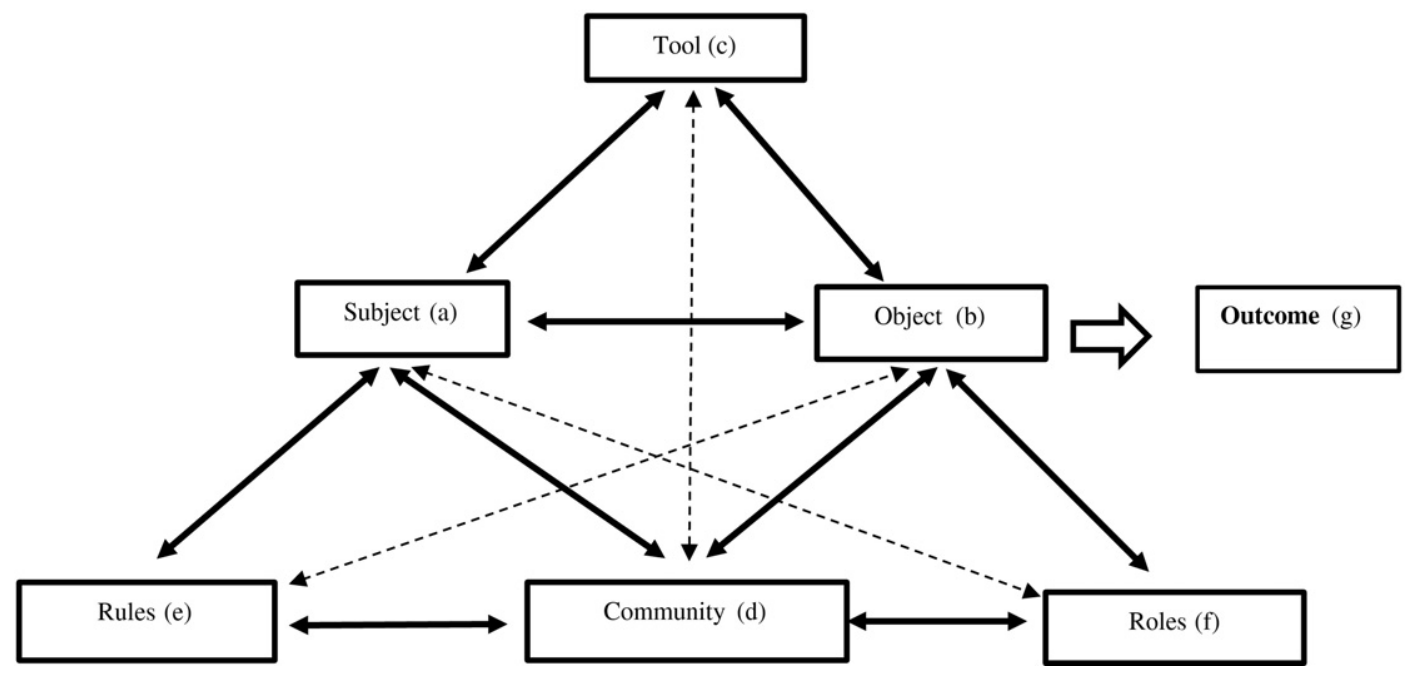

Fig. 1. Elements of activity theory (Engeström, 2001). 


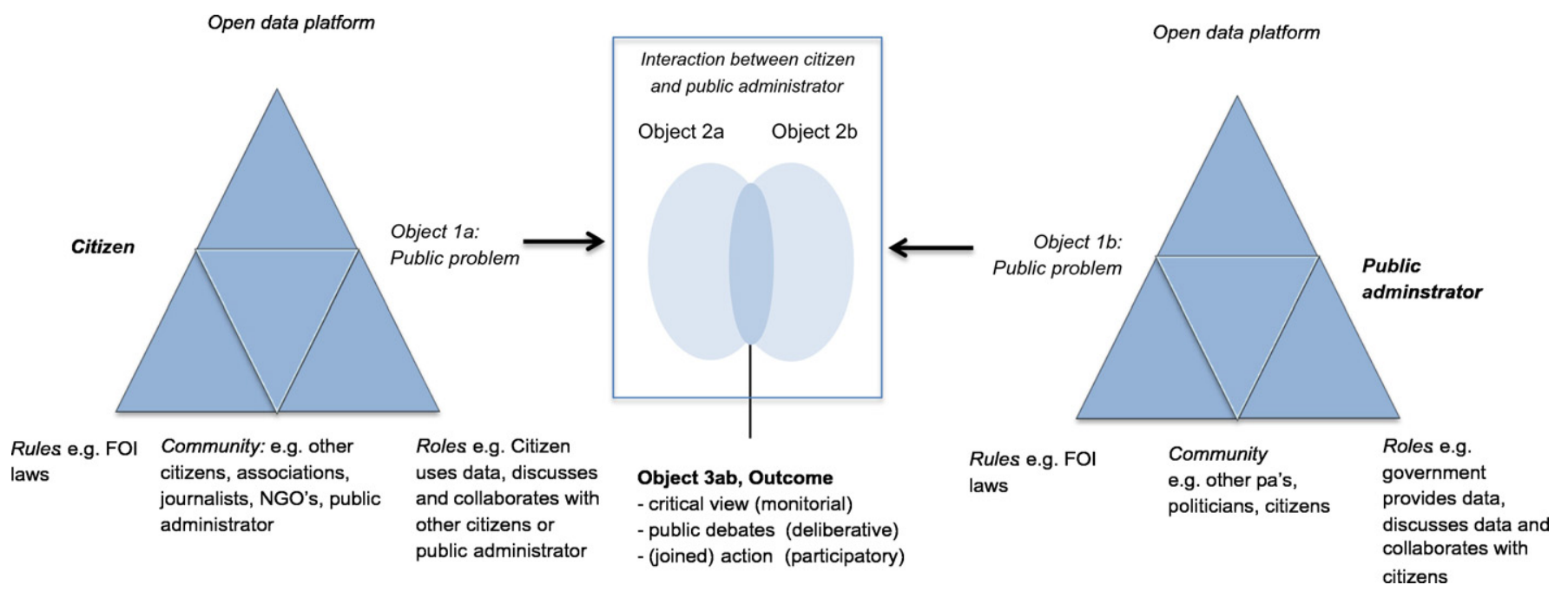

Fig. 2. Democratic Activity Model Of Open Data Use.

have a role as intermediary between government and citizens in a monitorial process. A company can collaborate with government aimed at innovation in a participatory process.

Within the activity system of the public administrator (PA), the subject can be a provider of information both proactively or reactively in a monitorial democracy. The public administrator can also facilitate dialogue (deliberative democracy) or be a partner in action (participatory democracy). The object of the use of open data can be government performance (monitorial) or a public problem (deliberative and participatory). The open data platform is the mediating tool, allowing access to data (monitorial), allowing interaction with individual citizens, journalists or citizen groups (deliberative), and providing opportunities for collaboration or joined action (participatory). For example, government could formulate a problem on a platform and work with citizens to coordinate a solution (Noveck, 2009). Rules refer to legal frameworks such as Privacy laws and Freedom of Information laws that oblige government to provide information. But also to informal strategies that can either facilitate or inhibit the system e.g. blame-avoidance strategies (Hood, 2007). The community of the public administrator might consist of stakeholders but also of other public administrators and political appointees within the administration. The administration might support or hinder the activities of the public administrator (Hood, 2007; Meijer, 2015). The role of government organizations varies. In a monitorial process the focus is on the provision of data whereas in a deliberative process the focus is on the facilitation of interaction and in a participatory democratic on co-creation and collaboration.

The activity systems of the citizen and public administrator both construct the outcome, thereby creating public value of open data regarding the object. The object, moves from an initial stage of raw material (object 1) (Engeström, 2001, p. 136) to a collectively meaningful object constructed by the interactions between the activity system of

Table 1

Overview of data collection.

\begin{tabular}{|c|c|c|}
\hline Scenario & Pilot site & Data collection \\
\hline $\begin{array}{l}\text { Budget } \\
\text { management }\end{array}$ & Prato & $\begin{array}{l}\text { Collective intelligence workshop with } 17 \text { public } \\
\text { administrators and users, Workshop with } 4 \text { experts, } \\
\text { followed by } 2 \text { interviews }\end{array}$ \\
\hline $\begin{array}{l}\text { Capacity } \\
\text { building }\end{array}$ & Dublin & $\begin{array}{l}\text { Collective intelligence workshop with } 18 \text { public } \\
\text { administrators and users, workshop with } 3 \text { experts } \\
\text { followed by } 2 \text { interviews and document analysis }\end{array}$ \\
\hline $\begin{array}{l}\text { Population } \\
\text { decline }\end{array}$ & Groningen & $\begin{array}{l}\text { Collective intelligence workshop with } 16 \text { public } \\
\text { administrators and users, } 3 \text { in-depth interviews and } \\
\text { document analysis }\end{array}$ \\
\hline
\end{tabular}

citizens (object 2a), and the activity system of the public administrator, (object 2b), mediated by the open data platform to a potentially shared understanding of a critical view (monitorial), public debates (deliberative) or collective action (participatory) (object 3ab). It should also be noted that the three outcomes can be part of the same process and a combination of outcomes is possible as well. Furthermore, activity systems are in constant movement (Engeström, 2001). After all, technology and user-needs are not static but can be both a one-off process on a single issue or decision as well as a continuous reflexive process among citizens and between citizens and public administrators (Williamson \& Meyerhoff Nielsen, 2013; Porwol, Ojo, \& Breslin, 2016). Finally, activity systems can be internally contradictory. "Contradictions are historically accumulating structural tensions within and between activity systems" (Engeström, 2001, p. 137). Identifying tensions helps to focus on possible problems.

\section{Research methods}

The study consisted of an exploratory qualitative multiple case method (Yin, 2003) based on three cases that illustrate the three types of democratic processes: Budget management (Prato, Italy), Capacity Building (Dublin, Ireland), Population Decline (Groningen, The Netherlands). Table 1 Overview of data collection shows how the data for each scenario was collected.

The study started with a collective intelligence scenario-based design workshops (see Table 1) with a range of 16-18 public administrators and users at each pilot site in the spring of 2015 (Hogan et al., 2015). These workshops focused on identifying barriers for the use of open data in relation with particular salient public problems, options to overcome these barriers and identifying user needs and requirements for an open data platform. Following, a workshop with 2-4 experts per case took place in June 2015 during a conference, ${ }^{1}$ consisting of both researchers and public administrators. The structure of the workshop was as follows. First, the participants were asked to identify the elements of the model based on their pilot site. Second, they were asked to identify possible tensions. Third, they were asked which implications these tensions have for the design of an open data platform. Lastly, one interviewer conducted follow-up semi-structured interviews with 7 experts: 2-3 respondents at each pilot site during September and October 2015. The respondents were involved in developing the scenarios

\footnotetext{
${ }^{1}$ A European Consortium meeting of the Horizon 2020 ROUTE-TO-PA (Raising Open and User friendly Transparency Enabling Technologies for Public Administration) project. The aim of this project is to develop innovative ICT's.
} 
for each pilot site and organized, conducted and reported the collective intelligence design workshops. The questions asked related to the elements of the model, possible tensions that influence the use of open data and finally how and open data platform to be developed could be useful for their scenario. The interviews were transcribed. In addition, government strategic plans and websites were analyzed, where available.

The data obtained from the different sources were analyzed led by the theoretical components of the DAMODU and a pattern matching logic. In addition, similarities and differences among the cases were analyzed (Cresswell, 2013). The findings resulted in a description of each pilot site based on the results of the workshop, interviews and document analysis, thereby identifying the components of the DAMODU; object, outcome, rules, community members involved and their different roles, tensions and requirements for the design of an open data platform.

\section{Results}

\subsection{City budget management, Prato, Italy}

Concerning the elements of the model, in Prato, the object, or government performance to be monitored, is city budget management. The administration, both at the political and bureaucratic level, aims to increase transparency on budget management and enhance dialogue with citizens. Subjects, citizens should be able to monitor how the municipality allocates the city budget and should be able to propose expenditure priorities and suggestions. The community consisting of citizens, associations, businesses and journalists, are heterogeneous in that it does not consist of one particular target group. Currently, the administration organizes face-to-face meetings in the budget preparatory phase $\left(\mathrm{R} 1^{2}\right)$. During these meetings citizens can ask for clarifications on the budget but do not have opportunities to influence the spending proposals nor the construction of the budget (Hogan et al., 2015). Turnout for these meetings depends on the topic to be discussed and the budget-decisions to be made (R1). The budget data currently available in PDF-format will be changed to an open data format, which according to the respondents is a complicated process due to budget and transparency related rules. The respondents indicated that a desired outcome of this scenario is that open data can facilitate access to administrative processes, which might eventually increase confidence in, and cooperation with the administration.

The respondents identified several tensions in this scenario e.g. a lack of confidence in the administration and the quality provided, a lack of comprehension of budget data, a lack of resources and administrators fear that open data and the tools will create high expectations (R1/2). (R1).

"There is a risk that there will be an explosion of requests from citizens"

The participants were also asked what they expect from a tool, the open data platform to be developed that can facilitate interaction between public administrators and citizens regarding their scenario. According to the respondents the platform should increase the comprehensibility of the data through visualization, but should also allow for comparisons of budget categories without losing coherence. It should facilitate data search and aggregation. There should be a space where budget suggestions and issues can be discussed between citizens and administrators. Posts should have the option to include datasets and graphs. Furthermore, the tools should enhance citizen's understanding of budget mechanisms.

\footnotetext{
2 The terms R1, R2 etc. are used to refer to the respondents participating in the interviews.
}

\subsection{Capacity building, Dublin, Ireland}

In terms of the elements of the model, the object for the open data platform in Dublin is capacity building, which focuses on increasing citizen engagement in a deliberative process with their city or more specifically their community.

The Dublin City Council is one of the founding partners of Dublinked. Dublinked is an idea and information-sharing network (Dublinked, 2015). The objective of Dublinked is to enable innovative applications by entrepreneurs and businesses in areas like public transportation, planning, social services and public facilities (Hogan et al., 2015, p. 19). Dublinked facilitates civic contribution to the debate on societal issues; specifically it encourages community conversations and builds community networks. The motivation for citizens and communities to engage is that it is a chance to find out what is already available and happening in their neighborhood and what is planned for their neighborhood in the future. The community is heterogeneous and consists of local authorities, elected representatives, resident associations and, lobby groups. Their role is to help in capacity building and community building (R7). The local authorities are the facilitators and data providers. There is political support for the project, but cost is an important barrier (R6). Data protection is mentioned by the participants of the workshop as an important rule that influences the release of data. Currently, Dublinked hosts more than 300 datasets on its open data portal (Dublinked, 2015). To encourage the re-use of the data Dublinked combines the open data portal with the promotion of an innovative network to enable new collaborations that solve urban challenges and create better services. The desired outcome of this scenario is the actual use of open data (Hogan et al., 2015).

"Certainly an outcome would be greater engagement in open data and greater trust in the deliberative democratic experience between the users and those who are paid to govern (...) That engagement and collaboration. And enhancing the quality of the data and of the quality of the decision derived from the data and the deliberation (R6)".

In this scenario several tensions can be identified, e.g. data quality, privacy issues and moderation of the platform. Furthermore, data may highlight or exacerbate social divisions: disadvantage areas compared to areas of affluence. Similarly, it must also be ensured that the digital divide does not compound the social divide (R6/7).

The open data platform to be developed should facilitate discussion according to the respondents. It should enable citizens to make their voice heard. A two-way flow of information needs to take place between public administration and citizens and from citizen to citizen. The platform is to present the data in an understandable format and should have an option for citizens to visualize a combination of relevant datasets to gain new insights about their city and neighborhood. It should enable citizens to easily find data that is useful and relevant to them so they can find out what is happening in their area. The platform should facilitate new types of community engagement around city data and create value for general users who may not have the technology skills to interact with the data available in raw formats (Hogan et al., 2015).

\subsection{Population decline, Groningen, The Netherlands}

Concerning the elements of the model, the object is the public problem population decline. One of the areas with the highest population decline in the Netherlands is situated in the Province of Groningen (Provincie Groningen, 2011). The administration currently facilitates citizen participation but would like to increasingly collaborate e.g. by stimulating citizens' initiatives and actions regarding population decline.

Citizens are personally concerned about the loss of their (public) services due to the consequences of population decline (R3). The 
community is heterogeneous consisting of citizens, public organizations (schools, health care organizations etc.) and private companies. Within the administration both the national, provincial and local government are involved (R4). Within the province, there is political will and support for open data and for guiding and anticipating population decline (Provincie Groningen, 2015). At the administrative level open data is not necessarily a priority and there is a lack of resources (R4/5). Currently, dialogue between citizens and public administration regarding population decline takes place in the form of face-to-face meetings. However, the perception is that these meetings are not very well attended (R4/5). There is not yet a technological platform where public administrators and citizens can interact and generate ideas and solutions together. The rules e.g. the re-use of public information, are perceived by the respondents as facilitating the release of datasets. The province has an open data portal with over 70 datasets. Datasets, relevant for population decline are currently limited on the portal and spread out over different organizations (R3/4, Hogan et al., 2015). Therefore, so far, open data has not been used in relation to population decline (R3/4). The desired outcome would be co-creation and interaction between citizens regarding the specific policy domain (R5, R3).

"Citizens can use government knowledge, such as open data, for their own initiatives. It is still a long way towards co-creation but we have to head that way" (R3)

The respondents identified several tensions in this scenario such as not sufficient administrative support (R4), a lack of best practices concerning the usefulness and value of open data, and the challenge of building a community, since the topic is broad and diverse (R5).

Regarding the open data platform to be developed, the respondents indicated that the platform should facilitate dialogue between citizen groups and between citizen groups and public administrators and the creation of ideas and solutions for policy issue. It is important that the open data platform facilitates insight in population decline in general and in regional differences. The issues in one region of Groningen might be very different from the other (Noordelijke Rekenkamer, 2015) and hence they might require different ideas and solutions (R4). The platform should complement other communication tools.

\section{Discussion}

The three cases provide important insights in the context of open data use. First of all, the cases illustrate the three democratic processes identified in the model (Table 2).

The budget management case illustrates a monitorial process, where the emphasis is on monitoring the government with a desirable outcome in terms of the facilitation of access to administrative processes and providing insight on how the money is spend. Citizens or journalists monitor the budget and have the role of a watchdog (Schudson, 1998), while public administrators facilitate and provide access to data. The capacity building case illustrates a deliberative process. In this scenario the emphasis is on communication, on dialogue and on the creation of a social network based on open data. The role of citizens is partner in dialogue and public administrators can facilitate this dialogue. The population decline case illustrates both deliberative and participatory processes. The emphasis is on collaboration and co-creation. The role of citizens is that of partner in the collaborative process, whereas the role of public administrators is facilitator of the collaboration process. It should however be pointed out that the three cases mostly contain elements of two democratic processes. The different processes are interconnected. Thus, the cases highlight that using open data to strengthen democracy can have very different meanings since democracy is a multifaceted concept.

Second, in line with Van den Hoven (2005) the findings show that an open data platform can facilitate different democratic processes by enabling the interaction between the activity system of the user and the activity system of the public administrator. In the monitorial scenario of Prato, the open data platform should facilitate access to budget data and allow interactive data analysis. If the data are open and interactive facilitated by the functionalities of the tools, journalists or other interested citizens can make comparisons and make open data visualizations such as tables, pies or line charts that are relevant for their specific problem. In the deliberative scenario in Dublin it is emphasized that the platform should facilitate access but should also facilitate decision making based on open data by e.g. an option of combining datasets and by making visualizations that is of interest to the user and his or her community. There should be options for personalization. In this case, the open data platform could facilitate deliberation. Open data visualizations such as a map or heat map made by the community and tailored to their needs can feed into the dialogue. Similarly Dalakiouridou et al. (2012) point out that in deliberative processes, open data platforms should include options for virtual discussion allowing reflection and consideration of issues.

In the participatory scenario in Groningen, the open data platform ensures access and interaction between public administrators and citizens but should also include functionalities that facilitate the co-creation of ideas and solutions based on open data, leading to (joined) actions or initiatives. In this line, Noveck (2015) argues that platforms can provide opportunities for collaborations between government and citizens to improve democratic processes. Government should draw on the expertise and knowledge of informed crowds; knowledge networks and talent pools could be called upon for e.g. hackathons (Noveck, 2015). The platform should facilitate collaborative environments where data can be shared, reused and co-created to feed into ideas and solutions for public problems (Dalakiouridou et al., 2012; Sandoval-Almazan \& Gil-Garcia, 2012; Noveck, 2015). In conclusion, platforms aimed at fostering democratic processes need different functionalities to facilitate these processes. However, as Birchall (2015) points out these functionalities require new skills from citizens, from auditors, analysts, translators to programmers. We argue in the

Table 2

Overview of the results of the Democratic Activity Model of Open Data Use.

\begin{tabular}{|c|c|c|c|}
\hline Use of open data & $\begin{array}{l}\text { Monitorial democracy } \\
\text { Monitoring government behavior }\end{array}$ & $\begin{array}{l}\text { Deliberative democracy } \\
\text { Feeding public debates }\end{array}$ & $\begin{array}{l}\text { Participatory democracy } \\
\text { Enabling joined action }\end{array}$ \\
\hline Object & Government performance & Public problem & Public problem \\
\hline Subject citizen & Watchdog & Partner in dialogue & Partner in collaborative process \\
\hline Tool & $\begin{array}{l}\text { Open data platform ensures } \\
\text { transparency by access to data, data } \\
\text { search and tools to visualize the data. It } \\
\text { facilitates data sharing. }\end{array}$ & $\begin{array}{l}\text { Open data platform ensures access and enables data } \\
\text { analysis, personalization, comparing and combining } \\
\text { datasets and feedback options. It facilitates participation } \\
\text { with debate and feedback options }\end{array}$ & $\begin{array}{l}\text { Open data platform ensures access, decision-making } \\
\text { tools, and the ability to co-produce data. It facilitates } \\
\text { collaboration with government and other stakeholders } \\
\text { e.g. refining solutions and working together }\end{array}$ \\
\hline Rules/mechanism & $\begin{array}{l}\text { Transparency, checks and balances, e.g. } \\
\text { foia laws, privacy laws }\end{array}$ & $\begin{array}{l}\text { Deliberation, open communication e.g. procedures } \\
\text { regarding participation }\end{array}$ & $\begin{array}{l}\text { Collaboration e.g. procedures regarding who is invited } \\
\text { (based on expertise)? }\end{array}$ \\
\hline Community & Government, journalists & Government and citizens & Government, citizens, businesses, researchers \\
\hline Role government & Provider of data & Facilitating dialogue & Partner in action \\
\hline Outcome & Critical view on government behavior & Contribution to debate about public problem & (Joined) action regarding a public problem \\
\hline
\end{tabular}


DAMODU that these skills reflect different roles. It stresses that different people with different roles or skills in a community are needed order to be able to transform data into a valuable outcome for public problems.

Third, it shows that transparency related rules and regulations such as FOI laws and privacy laws can either facilitate or hinder the release of open data and consequently the use of open data. Some public problems seem to be more sensitive to privacy issues than others, which may hinder the release of information.

Finally, tensions were identified in the cases. First, the community or the organization in which the public administrator operates is not always perceived as supportive. This is in line with structural and cultural organizational barriers identified by other scholars (Janssen et al., 2012; Barry \& Bannister, 2014; Conradie \& Choenni, 2014; Meijer, 2015; Ruijer \& Huff, 2016). In some cases there is political support but a lack of administrative support, or there is a lack of resources. These elements hinder the provision of data, but also for example the moderation of the platform. Second, in the community of the citizens, several tensions were pointed out as well such as a lack of confidence in the administration in the monitorial scenario, and the concern of how to facilitate or build a community, important for deliberative and participatory processes. In order to build a community it is important that users are motivated. Motivations for citizens to participate is affected by the enjoyment of participating, the perception of the amount of resources needed to contribute or having an interest in public problems (Wijnhoven et al., 2015; Hutter, Fuller, \& Koch, 2011) Furthermore, the object, the problem should not be too complex. Wijnhoven et al. (2015) show if projects are perceived as too complicated and people believe that they do not have the knowledge to contribute in a meaningful way, they may not participate. Third, across the cases tensions regarding open data itself were identified, which relate to access, quality and the lack of data, which is in line with citizen barriers found by other studies (Janssen et al., 2012; Meijer, 2015; Zuiderwijk, Janssen, Choenni, Meijer, \& Sheikh Alibaks, 2012). These tensions need to be solved in order for the platform to reach its full potential. As pointed out earlier, Engeström (2001, p. 135; 2000, p. 960) stresses that (the overcoming of) tensions in the activity model are key to process of learning, and function as the driving force of change and development.

Finally, some limitations can be pointed out. This study was a qualitative explanatory heuristic model aimed at better understanding open data practices. It did not have the intention to be able to explain all open data practices, but focused on practices in a democratic context and not for instance on innovation which is another important aim of open data. Furthermore, the three cases were focused on three scenarios in a local context. These scenarios did not encompass all democratic processes such as using open data for more informed choices in referenda, lobbying or organizing protests. Additionally, this study did not focus on national cultural factors that could possibly have influenced the findings. A follow-up study could take into account these issues.

\section{Conclusion}

In this study monitorial, deliberative and participatory democratic processes were analyzed as part of the context in which the usage of open data takes place. The usage of open data by citizen users and public administration users were considered as two separate activity systems, interacting together in a network, mediated by a tool, an open data platform. The open data platform can facilitate transforming the raw data into meaningful information constructed collectively by the activity system of the public administrator and citizens, that facilitates monitorial, deliberative and participatory processes. This resulted in the Democratic Activity Model of Open Data Use (DAMODU). The model was illustrated by three cases. Based on the model and the empirical findings three important conclusions can be drawn.

First, this paper provided a better conceptual understanding of open data usage. In contrast with previous efforts, we did not focus on user requirements but instead on user activities. Activity Theory (Engeström,
2000) was used to provide a formal understanding of the various elements involved in open data usage: object, subject, tool, rules, community, government role and outcome. Activity Theory has been used in egovernment research (Ojo et al., 2011) but its application to open data is innovative and promising. We developed a heuristic model with the various elements of the democratic context and how these elements influence the use of open data. All these elements influence the outcome of the activity and can be considered as preconditions for effective use of open data aimed at enhancing monitorial, deliberative and participatory democratic processes. The value of this model is that it provides a better conceptual understanding of the relation between open data and the activities of citizens and governments in various types of democratic processes.

Second, the explanatory model helps to identify the challenges for open data use for democracy. As with all democratic processes, it 'takes two to tango'. From the side of the user we found for open data to be effective users should feel a connection to the object or public problem that motivates them to use open data. After all, these processes thrive on the extent to which there is an active community of users. Individual users may have an interest in exploring a problem but if there is not a well-functioning community there will hardly be democratic interactions. On the side of the administration, information provision and data quality are crucial. If public administrators do not provide the information needed or if citizens do not have access to crucial data due to privacy or security rules, they will or cannot engage in the democratic activities of monitoring, deliberating and participating. The DAMODU enables us to identify tensions that influence the use of open data with much more precision. For instance, in the deliberative case we found a tension between citizens and public administrator and their community. In the community of the public administrators, participants point out either a lack of management support, political support or lack of resources. These tensions need to be solved over time in order for the open data platforms to have an impact on democratic processes, something that is currently a problematic issue (Attard et al., 2015; Worthy, 2015).

Third, the paper provides the basis for a more context-sensitive design of open data platforms. The concept of democracy was opened up and it was shown that a variety of relations between open data and monitorial, deliberative and participatory democratic processes exist. These three courses of democratic action differ considerably and result in different requirements for open data platforms in order to facilitate the continuous reflexive monitoring, dialogue and collaboration between citizens and public administrators (Williamson \& Meyerhoff Nielsen, 2013; Porwol et al., 2016). Our analysis highlights that the three local governments all aim to use open data to support democratic processes but the requirements for the open data platform differ considerably. These different requirements could be a start to a context-sensitive design of an open data platform. Our analysis identifies of a variety of functionalities that, once incorporated, enable the tool to facilitate different kinds of democratic interactions. Finally, it should be noted that even though this study focused on the design of open data platforms it does not imply that democratic processes regarding open data take place only on online open data platforms. Off-line communication around open data is important as well, as was pointed out in the population decline case.

In sum, making open data work is a key challenge for governments. The DAMODU forms an important addition to present provider or user-centric approaches since it stresses the variety of relations between citizens and governments in different democratic contexts. We acknowledge that our model does not make the design of open data platforms any easier but, at the same time, the emphasis on sensitivity to context provides a basis for platforms that actually support various democratic processes.

\section{Acknowledgments}

This project has received funding from the European Union's Horizon 2020 - Research and Innovation Framework Programme under 
grant agreement No 645860. The authors would like to thank their ROUTE-TO-PA colleagues and the anonymous reviewers for their valuable contributions.

\section{References}

Attard, J., Orlandi, F., Scerri, S., \& Auer, S. (2015). A systematic review of open government data initiatives. Government Information Quarterly, 32(4), 399-418.

Barry, E., \& Bannister, F. (2014). Barriers to open data release: A view from the top. Information Polity, 19, 129-152.

Birchall, C. (2015). 'Data.gov-in-a-box': Delimiting transparency. European Journal of Social Theory, 18(2), 185-202.

Birkinshaw, P. (2006). Transparency as a human right. In C. Hood, \& D. Heald (Eds.), Transparency: The key to better governance? (pp. 47-58). Oxford: Oxford University Press.

Boyte, H. (2005). Reframing democracy: Governance, civic agency and politics. Public Administration Review, 65(5), 518-528

Coleman, S., \& Moss, G. (2012). Under construction: The field of online deliberation research. Journal of Information Technology \& Politics, 9(1), 1-15.

Conradie, P., \& Choenni, S. (2014). On the barriers for local government releasing open data. Government Information Quarterly, 31(1), 10-17.

Cresswell, J. W. (2013). Qualitative Inquiry and Research Design. Choosing among five approaches (3rd ed.). Thousand Oaks, CA: Sage Publications.

Dalakiouridou, E., Smith, S., Tambouris, E., \& Tarabanis, K. (2012). Electronic participation policies and initiatives in the European Union institutions. Social Science Computer Review, 30(3), 297-323.

Dawes, S., \& Helbig, N. (2010). Information strategies for open government: Challenges and prospects for deriving public value from government transparency. Electronic Government, 6228, 50-60.

Dublinked (2015). retrieved on September 20, 2015 from www.dublincity.ie.

Engeström, Y. (2000). Activity theory as a framework for analyzing and redesigning work. Ergonomics, 43(7), 960-974.

Engeström, Y. (2001). Expansive learning at work: Toward an activity theoretical reconceptualization. Journal of Education and Work, 14(1), 133-156.

Engeström, Y. (2005). Developmental Work Research. Expanding Activity Theory in PracticeBerlin: International Cultural-historical Human Sciences.

Engeström, Y. (2008). Enriching activity theory without shortcuts. Interacting with computers, 20, 256-259.

Habermas, J. (1989). The structural transformation of the public sphere. Cambridge: Polity Press.

Harrison, T., \& Sayogo, D. (2014). Transparency, participation and accountability practices in open government: A comparative study. Government Information Quarterly, 31 513-525.

Hogan, M., Harney, O., Boscolo, P., Palmisano, E., Andriessen, J., Ruijer, E., et al. (2015). D2. 3 User stories on Open Data and Transparency. Route-To-PA.

Hood, C. (2007). What happens when transparency meets blame-avoidance. Public Management Review, 9(2), 191-210.

Huijboom, N., \& Van den Broek, T. (2011). Open data: An international comparison of strategies. European Journal of ePractice, 1-13.

Hutter, K., Fuller, J., \& Koch, G. (2011). Why citizens engage in open government platforms? Informatik.

Jaeger, P. T., Bertot, J. C., \& Shilton, K. (2012). Information policy and social media: Framing government-citizen web 2.0 interactions. In Web 2.0 technologies and democratic governance (pp. 11-25). New York. Springer.

Janssen, K. (2011). The influence of the PSI directive on open government data: An overview of. Government Information Quarterly, 28, 446-456.

Janssen, M., Charalabidis, Y., \& Zuiderwijk, A. (2012). Benefits, adoption barriers and myths of open data and open government. Information Systems Management, 29, 258-268.

Jonassen, D., \& Rohrer-Murphy, L. (1999). Activity theory as a framework for designing constructivist learning environments. Educational Technology Research and Development, 47(1), 61-79.

Keane, J. (2009). Life and death of democracy. London: Simon and Schuster.

Kuuti, K. (1996). Activity theory as a potential framework for human-computer interaction research. In B. Nardi (Ed.), Context and consciousness: Activity theory and human computer interaction (pp. 17-44). Massachusetts Institute of Technology.

Kuuti, K. (1999). Activity theory, transformation of work and information systems design. In Y. Engeström, R. Miettinen, \& R. Punamäki (Eds.), Perspectives on activity theory (pp. 360-376). Cambridge: Cambridge University Press.
Lourenç, R. P. (2015). An analysis of open government portals: A perspective of transparency for accountability. Government Information Quarterly, 32, 323-332.

Meijer, A. J. (2012). The do it yourself state. The future of participatory democracy Information Polity, 17(3-4), 303-314.

Meijer, A. (2015). E-governance innovation: Barriers and strategies. Government Information Quarterly, 32, 198-206.

Meijer, A., Curtin, D., \& Hillebrandt, M. (2012). Open government: Connecting vision and voice. International Review of Administrative Sciences, 78(1), 10-29.

Nardi, B. (1996). Context and consciousness: Activity theory and human-computer interaction. Cambridge, MA: MIT Press

Noveck, B. (2009). Wiki government. How technology can make government better, democracy stronger and citizens more powerful. Washington, DC: Brookings Institution Press.

Noveck, B. (2015). Smart citizens, smarter state. The Technologies of Expertise and the future of governing. Cambridge, MA: Harvard University Press.

Ojo, A., Janowski, T., \& Estevez, E. (2011). Building theoretical foundations for electronic government benchmarking. Electronic Government, 6846, 13-25.

Porwol, L., Ojo, A., \& Breslin, J. (2016). An ontology for next generation e-participation initiatives. Government Information Quarterly, 33(3), 583-594.

Provincie Groningen (2011). Kijk op Krimp in Groningen.

Provincie Groningen (2015). Vol vertrouwen. College Akkoord Provincie Groningen 2015 2019, Groningen.

Noordelijke Rekenkamer (2015). Het krimpbeleid van de provincie Groningen. Assen: Noordelijke Rekenkamer.

Ruijer, H. (2016). Proactive transparency in the United States and the Netherlands. The role of government communication officials. The American Review of Public Administration, 1-22.

Ruijer, H., \& Huff, R. (2016). Breaking through barriers: The impact of organizational culture on open government reform. Transforming Government: People, Process and Policy, 10(2), 335-350.

Sandoval-Almazan, R., \& Gil-Garcia, R. (2012). Are government e-portals evolving towards more interaction, participation and collaboration? Revisiting the rhetoric of e-government among municipalities. Government Information Quarterly, s72-s81.

Schudson, M. (1998). The good citizen: A history of American civic life. New York: The Free Press.

Schudson, M. (2000). Good citizens and bad history: Today's political ideas in historical perspective. The Communication Review, 4(1), 1-19.

Strömbäck, J. (2005). In search of a standard: Four models of democracy and their normative implications for journalism. Journalism Studies, 6(3), 331-345.

Van den Hoven, J. (2005). E-democracy, E-contestation and the monitorial citizen. Ethics and Information Technology, 7, 51-59.

Van Velzen, L., Van der Geest, T., \& Ter Hedde, M. D. (2009). Requirements engineering for e-government services: A citizens-centric approach and case study. Governmen Information Quarterly, 26, 477-486.

Verhulst, S., \& Young, A. (2016). Open Data impact, when demand and supply meet. Key finding of the open data Impact case studies. Opgehaald van. thegovlab.orghttp:/ odimpact.org/key-findings.html

Wijnhoven, F., Ehrenhard, M., \& Kuhn, J. (2015). Open government objectives and participation motivations. Government Information Quarterly, 32, 30-42.

Williamson, A., \& Meyerhoff Nielsen, M. (2013). Strategies for building and sustaining successful user-engagement. A model, tool box and check list for a one-off or cyclica process. In P. Parycek, \& N. Edelmann (Eds.), Conference for E-democracy and open government (pp. 439-448). Krems, Austria: Danube University.

Worthy, B. (2015). The impact of open data in the UK: Complex, unpredictable and political. Public Administration, 93(3), 788-805.

Yin, R. (2003). Case study research. Design and methods (3rd ed.). Thousand Oaks, CA Sage Publications.

Zaller, J. (2003). A new standard of news quality: Burglar alarms for the monitorial citizen Political Communication, 20(2), 109-130.

Zuiderwijk, A., Janssen, M., Choenni, S., Meijer, R., \& Sheikh Alibaks, R. (2012). Socio-technical impediments of open data. Electronic Journal of eGovernment, 10(2), 156-172.

Erna Ruijer is postdoctoral researcher at the Utrecht University School of Governance.

Stephan Grimmelikhuijsen is assistant professor at the Utrecht University School of Governance.

Albert Meijer is professor at the Utrecht University School of Governance. 